\title{
The Belterra Clay on the bauxite deposits of Rondon do Pará, Eastern Amazon
}

\author{
Leonardo Boiadeiro Ayres Negrão*, Marcondes Lima da Costaㄹ, Herbert Pöllmann²
}

\begin{abstract}
Bauxite deposits in the Amazon region are commonly covered by yellowish clays which can reach up to $25 \mathrm{~m}$ thick, known as Belterra Clay (BTC). In Rondon do Pará, Eastern Amazon, BTC is $13 \mathrm{~m}$ thick and covers world-class bauxite reserves. Three pilot bauxite mines were investigated in Rondon do Para for an initial characterization of the local BTC. In discordant contact with the lateritic profile, the BTC has reddish brown colors at its base to ocher tones towards the top. It has a massive structure with silt-clayey texture and nodular bauxitic fragments at its base. Rietveld mineral quantification of the material attests that it is dominated by kaolinite, with goethite, gibbsite, hematite, anatase and residual quartz. The thermal behavior of the material also confirms its mineralogical composition. Kaolinite is of low structural order, which was considered the main difficulty in the application of the Rietveld method. Goethite has up to 33 mol\% of Al. As observed by scanning electron microscopy (SEM), the minerals represent pseudo-hexagonal crystals measuring from 150 to $700 \mathrm{~nm}$. The BTC in the studied area is correlated to BTC on others bauxitic deposits of the Amazon region, suggesting this material experienced the same genesis and geological evolution, probably during the Pliocene.
\end{abstract}

KEYWORDS: Bauxite; Mineralogy, Kaolinite, Al-Goethite, Rietveld, Chemistry

\section{INTRODUCTION}

Bauxites are covered by thick yellowish clay in the Amazon region, denominated Belterra Clay (BTC) (Truckenbrodt $\&$ Kotschoubey 1981, Bardossy \& Aleva 1989, Truckenbrodt et al. 1991, Horbe \& Costa 1999). The term was coined by Sombroek's (1966) observations of similar clays, but not related to bauxites, in Belterra, Lower Amazon region. The BTC typically lies on the top of plateaus held by lateritic bauxite sequences, has been ground to the agricultural expansion (mostly soybean) in Eastern Amazon and was recently subject for red ceramic' sintering purposes (Barreto $\&$ Costa 2018).

The origin of BTC is firstly related to the deposition of a huge lake, with sediments coming from the Andes during the Plio-Pleistocene (Sombroek, 1966). However, the lack of sedimentary structures and apparent homogeneity of the BTC raised a range of discussions on its genesis, relating it to the strong weathered material of the upper part of the Barreiras Formation (Dennen \& Norton, 1977); to mud flow or sheet flood deposits from the Plio-Pleistocene (Truckenbrodt \& Kotschoubey, 1981); to the dealuminization of a previous bauxite crust (Bardossy \& Aleva 1989, Tardy 1993); to in situ formation by weathering with termites' contributions (Truckenbrodt et al. 1991); and as result of geochemical differentiation of bauxites under intense tropical forest (Lucas, 1993). After extensive fieldwork, mineralogical and geochemical studies, Kronberg et al. (1982), Horbe \& Costa (1997, 1999, 2005) and Costa et al. (2014) concluded that the BTC corresponds to yellowish latosols and considered its formation as in situ tropical weathering degradation of former lateritic bauxite sequences. Williams et al. (2010) proposed that the BTC was formed by the deposition of Saharan dust from the Bodélé Depression transported by trade winds across the Atlantic Ocean. Although Abouchami et al. (2013) compared geochemical and isotopic signatures of these sediments and the BTC, no genetic relation was found. The genesis of the BTC is not yet completely understood, but it is well accepted that this material has a strong relation to the bauxites.

The intensified research on bauxites in the Eastern Amazon, led to the "rediscovery" (Prazeres Filho et al. 2015) of what has been considered one of the seven largest world-class bauxite deposits (Oliveira et al. 2016), located

1Instituto de Geociências, Universidade Federal do Pará - Belém (PA),Brazil.E-mail:boiadeiro.negrao@gmail.com,marcondeslc@gmail.com ${ }^{2}$ Institut für Geowissenschaften, Martin-Luther-Universität Halle-Wittenberg - Halle, Germany. E-mail: herbert.poellmann@geo.uni-halle.de *Corresponding author

Manuscript ID: 20170128: Received on: 10/31/2017. Approved on: 04/06/2018 
in Rondon do Pará. The company Votorantim Metais developed three pilot mines for ore evaluation, exposing up to $13 \mathrm{~m}$ thick of BTC over the bauxites. This work presents a mineralogical, micromorphological and chemical characterization of the BTC in Rondon do Pará and discusses its importance in order to show its possible relationship to bauxite, as well as to contribute to the understanding of this clay packet's origin.

\section{STUDY AREA}

The Rondon do Pará bauxite deposits are located in the southeast of the Pará State, Brazil, distributed in the counties of Dom Eliseu, Goianésia do Sul and Rondon do Pará (Fig. 1), situated approximately $540 \mathrm{~km}$ south of
Belém, the capital of Pará State. The relief of the region is dominated by plateaus reaching near $500 \mathrm{~km}^{2}$ in area, with altitudes from 180 to $350 \mathrm{~m}$ (Fig. 1), whereas the local drainage runs on a dissected lower relief. The plateaus are held by well-developed laterite-bauxitic profiles that comprise part of the Paragominas Bauxite Province, an area of approximately $50.000 \mathrm{~km}^{2}$ in size with bauxites in the Eastern Amazon (Kotschoubey et al. 2005). The tertiary partially weathered sedimentary rocks of the Ipixuna and Itapecuru Formations (Grajaú Basin) are the main bedrocks of these bauxites.

The investigated pilot mines are nearly $60 \mathrm{~km}$ from the city of Rondon do Pará. On distinct plateaus, they are denominated as Décio $(22 \mathrm{~N}, 809,895 \mathrm{~m} \mathrm{E}, 9,501,218 \mathrm{~m} \mathrm{~S})$, Branco $(80,700 \mathrm{~m} \mathrm{E}, 9,521,770 \mathrm{~m} \mathrm{~S})$ and Ciríaco $(801,793 \mathrm{~m} \mathrm{E}$, $9,523,797 \mathrm{~m} \mathrm{~S}$ ). Along each mine, the BTC covers complete
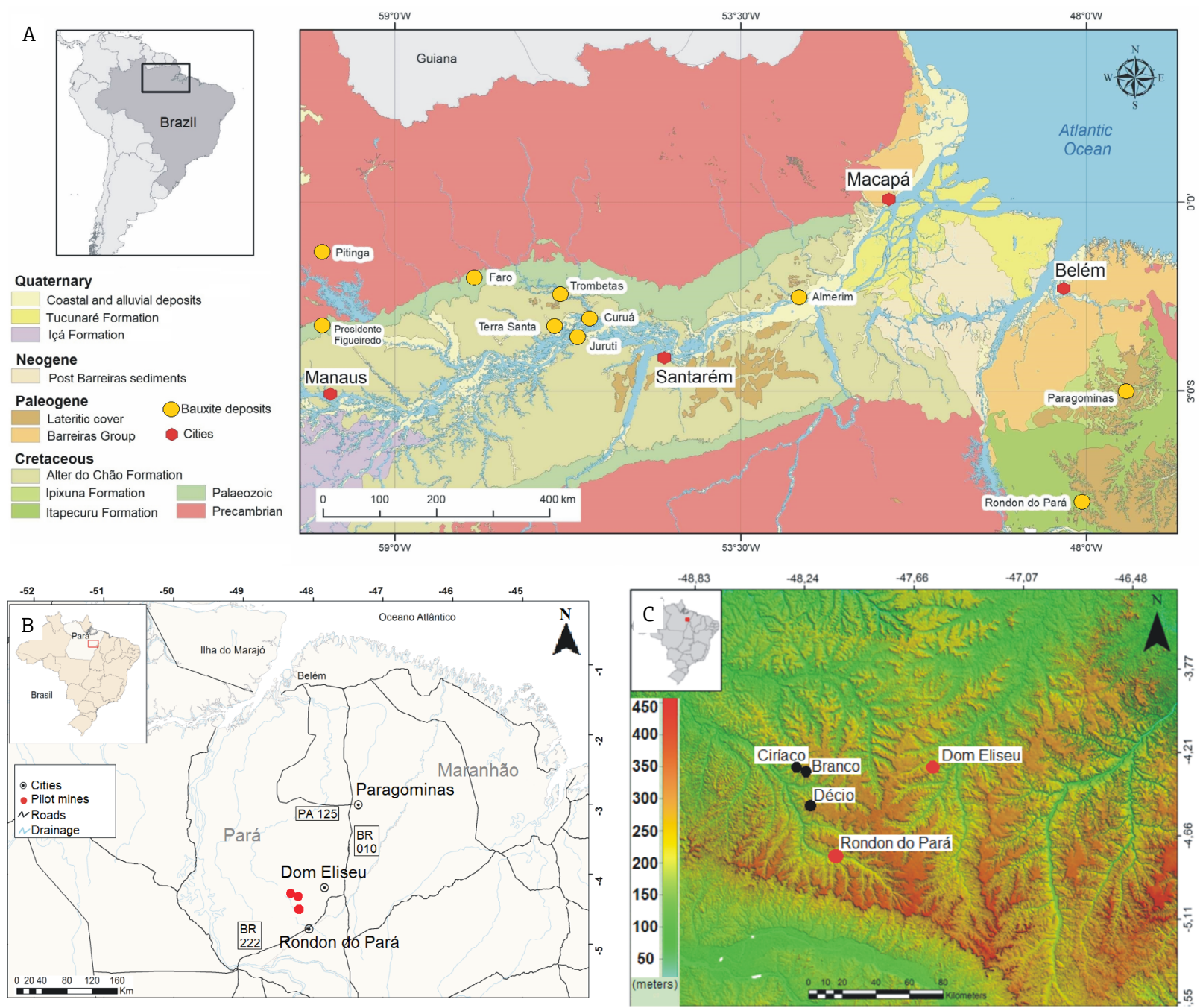

Figure 1. (A) Simplified geological map of eastern Amazon showing the main bauxite deposits with related Belterra Clay covers, modified from Bizzi et al. (2003); (B) localization of the study area; (C) SRTM topography of the study area and adjoins showing the intense drainage erosion giving rise to plateaus on a lower flat landscape. 
lateritic-bauxite regoliths with well-defined horizons and nearly the same general physical characteristics.

\section{MATERIAL AND METHODS}

The fieldwork consisted of geological profile descriptions and collection of fourteen samples from the top, middle and bottom of the Belterra Clay packets, exposed in the front of the pilot mines of the Votorantim Metais' research area.

The samples were labeled, photographed and described regarding its colors (according to the Munsell Chart of Colors) and textural aspects. Thereafter, they were submitted for granulometric analyses using an ANALYSETTE 22 MicroTec Plus laser granulometer. The samples were further homogenized, quartered and carefully sprayed in agate mortar to follow X-ray diffraction and X-ray fluorescence analyses. Samples in nature were also selected for micromorphological and thermal analysis.

All the analytical procedures were carried out in the laboratories of the Instituto de Geociências, in the Universidade Federal do Pará, Brazil, except the thermal analyses, performed in the University Martin-Luther Halle-Wittenberg, in Halle an der Saale, Germany.

\section{Micromorphology}

Four samples were heated to $100^{\circ} \mathrm{C}$ for 24 hours and metalized (Au) in Emitech K550X metalizer. These samples were characterized micro morphologically using Scanning Electron Microscope (SEM) Zeiss Sigma-VP, with a coupled energy-dispersive $\mathrm{X}$-ray spectrometer Sedona-SD.

\section{Mineralogical analysis}

The minerals were identified by X-ray Diffraction (XRD), through the powder diffraction method, using a Bruker D2 Phaser diffractometer equipped with a $\mathrm{Cu}$ anode, goniometer $\Theta-\Theta(R=141.1 \mathrm{~mm})$, angular range $0-70^{\circ}$, step $0.01^{\circ}$ and time per step 1s. A Rietveld analysis (Rietveld 1969) was performed to quantify the mineralogy of the material, using additional fluorite $(10 \%)$ as internal standard. The background of the diffractograms was defined using the method of Sonneveld and Visser (1975), provided by the software HighScore Plus 3.5. Further configurations during the refinements included the use of Pseudo-Voigt profile function, refinement of scale factor, unit cell parameters and $\mathrm{W}$ profile parameters, for all minerals. Some diffractograms also had their preferred orientation (00l) refined for gibbsite and/or kaolinite. The FIZ Karsruhe crystal structure database was accessed to obtain the structural models (Tab. 1) used in the refinement, with provided access by CAPES foundation through the website Bases de Estruturas Cristalinas.

The Fe-Al substitution in the $\mathrm{FeOOH}-\mathrm{AlOOH}$ solid solution was determined after Schulze's (1984) method, using the obtained cell parameters from the Rietveld analysis.

\section{Chemical analysis}

Prepared fused pearls of the samples were analyzed for chemicals of major oxide composition using X-ray Fluorescence (XRF). The analyses were performed with a wave dispersive $\mathrm{X}$-ray Spectrometer model Axio Minerals of PANalytical (Rh anode) and maximum power of $2.4 \mathrm{KW}$. Loss on ignition (LOI) was determined by $1,000^{\circ} \mathrm{C}$ calcination. Stoichiometric mineral quantification was performed based on the XRF chemical results, to compare with the Rietveld mineral quantifications.

\section{Amorphous characterization}

The Fe and $\mathrm{Si}$ amorphous concentration in the samples were determined by the colorimetric method. The amorphous Fe dissolution was performed according to McKeague \& Day (1966) by adding $10 \mathrm{ml}$ of oxalic acid solution and ammonium oxalate ( $0.2 \mathrm{M}, \mathrm{pH} 3.0)$ to $250 \mathrm{mg}$ of sample, to complex the amorphous $\mathrm{Fe}$ in a single extraction. Thereafter, the sample was agitated and remained in the dark for $4 \mathrm{~h}$.

Amorphous Si was extracted after DeMaster (1981) by leaching $30 \mathrm{mg}$ of samples in $40 \mathrm{ml}$ of $\mathrm{Na}_{2} \mathrm{O}_{3}$ solution at $1 \%$ and under $85^{\circ} \mathrm{C}$ for $4 \mathrm{~h}$. The results were then converted to $\mathrm{SiO}_{2}$ and $\mathrm{Fe}_{2} \mathrm{O}_{3}$ weight percentage.

\section{Thermal behavior}

The thermal behavior of the BTC was used to identify the mineral phase's transitions. A TG/DTA320U Seiko thermal analyzer was used to perform Thermogravimetic (TGA) and

Table 1. Structural models used in the Rietveld refinement.

\begin{tabular}{l|c|c|c}
\hline Mineral & Crystal system & Authors & ICSD code \\
\hline Kaolinite & Triclinic C1 & $\begin{array}{c}\text { Bish \& Von } \\
\text { Dreele (1989) }\end{array}$ & 63192 \\
\hline Goethite & $\begin{array}{c}\text { Orthorhombic } \\
\text { Pbnm }\end{array}$ & $\begin{array}{c}\text { Li Deyu et al. } \\
(2006)\end{array}$ & 109411 \\
\hline Gibbsite & $\begin{array}{c}\text { Monoclinic P 1 } \\
21 / n \text { 1 }\end{array}$ & $\begin{array}{c}\text { Saalfeld \& } \\
\text { Wedde (1974) }\end{array}$ & 6162 \\
\hline Hematite & $\begin{array}{c}\text { Trigonal } R \text {-3 c H } \\
\text { Anatase }\end{array}$ & $\begin{array}{c}\text { Tetragonal } \text { et al. } \\
\text { (1996) }\end{array}$ & 82137 a \\
\hline Quartz & $\begin{array}{c}\text { Weirich et al. } \\
(2000)\end{array}$ & 92363 \\
\hline
\end{tabular}


Differential Thermal analyses (DTA). Approximately $10 \mathrm{mg}$ of sample was heated from 25 to $1,050^{\circ} \mathrm{C}$ in a heating rate of $10^{\circ} \mathrm{C} \cdot \mathrm{min}^{-1}$. The first derivate of DTA was performed to better individualize dehydroxylation events.

\section{RESULTS}

\section{Lateritic-bauxite profile}

The lateritic-bauxite sequences are similar along the three pilot mines and can be subdivided into well-defined horizons, which present slight thickness differences among the pilot mines.

A general description (Pantoja 2015) of this sequence, from the basis to the top, is: a clayey horizon composed of saprolitic material from rocks of the Itapecuru Formation followed by massive bauxite, massive iron-aluminous crust, a dismantled iron-aluminous crust, ferruginous spherulites, and a horizon with bauxite nodules within a clayey matrix. In discordant contact with the lateritic profile, lies the BTC, with reddish brown colors at the base and ocher tones towards the top (Fig. 2).

Gibbsite, hematite, $\mathrm{Al}$-goethite, kaolinite and anatase represent the general mineralogical composition of the profiles. Gibbsite predominates in the bauxite, whereas the iron-rich horizons are ruled by hematite and Al-goethite. Kaolinite is the main phase in the clayey horizons and anatase displays similar contents along the profile, being enriched in the BTC cover.

\section{Belterra Clay}

\section{Texture and disposition}

The BTC can reach up to $13 \mathrm{~m}$ thickness in the studied pilot mines. An irregular and discordant contact, frequently with an erosive aspect, is seen between the BTC and the lateritic bauxitic profiles along the pilot mines. This contact occurs with the upper nodular bauxitic horizon in the Décio and Branco pilot mines (Fig. 2), whereas the BTC lays directly over the ferruginous spherulites in the Ciríaco, where a horizon with bauxitic nodules is not individualized. Along the contacts, both the ferruginous spherulites and bauxitic nodules are fining upwards in the sequence and are frequently mixed.

The BTC has a massive structure with silt-clayey texture. The material presents reddish brown colors (5 YR 5/8) predominating at its basis, which fades to ocher tones (10 YR 10/6) to the top.

With respect to its particles, silt grain size is dominant $(-85 \%)$, followed by clay $(-13 \%)$ and sand $(-2 \%)$.
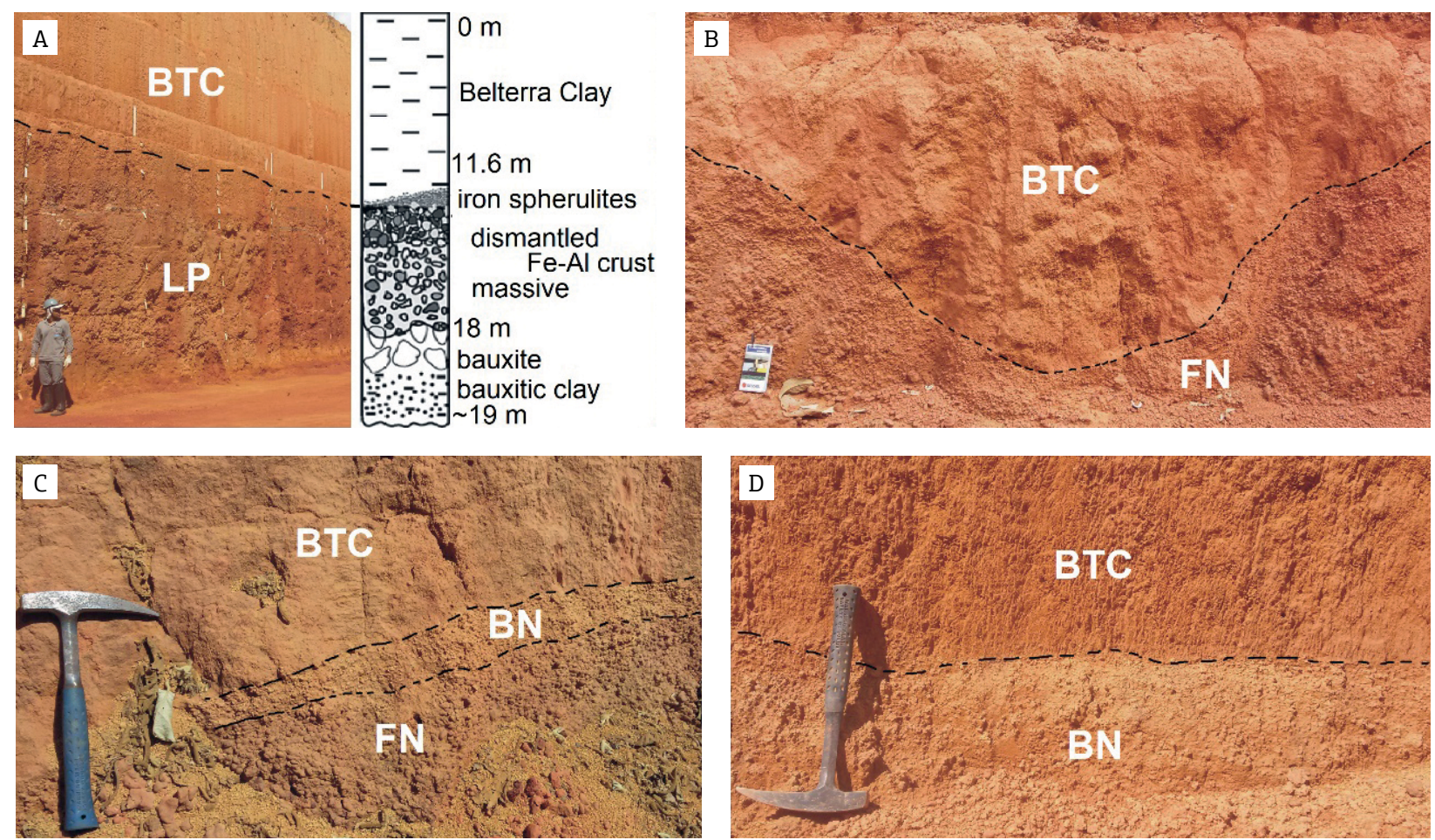

Figure 2. (A) General view of the Branco bauxite pilot mine showing the lateritic profile (LP) with its scheme (right) and the thick Belterra Clay (BTC) on the top; (B) Erosive paleochannel developed in the ferruginous nodules (FN) horizon fulfilled with the Belterra Clay in the Ciríaco mine; (C) Sharp contact between BTC and the underlying bauxitic nodules (BN) horizon and ferruginous nodules (FN) horizon at Décio mine; (D) contact between the BTC and the BN horizon in the Branco mine. 
Millimetric fragments of nodular bauxite and ferruginous spherulites are also common within the clayey material, predominating at the bottom of the sequences.

\section{Mineralogy}

The BTC shares the same mineralogical phases of the underlying bauxites in the three pilot mines, but with strong different proportions. After the Rietveld quantification, the content percentages (in descending order) are: kaolinite, goethite, gibbsite, hematite, anatase and quartz (Figs. 3 and 4).

Kaolinite is the main mineral (55.9 to $75.3 \%$ ) of BTC (Fig. 4, Tab. 2). Its contents increase slightly from bottom to top in the Ciríaco mine, reaching a maximum of $64.6 \%$ according to Rietveld results. However, in the Décio and Branco mines,

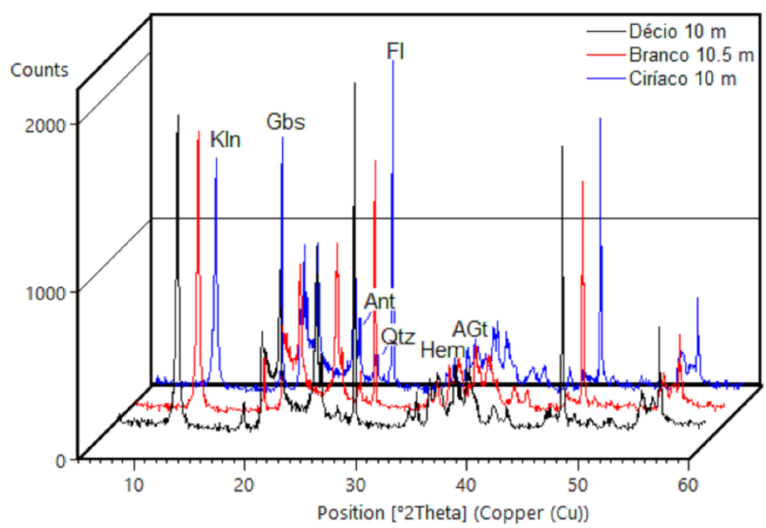

Kln: kaolinite, Gbs: gibbsite, AGt: Al-goethite, Qtz: quartz, Ant: anatase, Fl: fluorite (internal standard).

Figure 3. X-ray patterns of the BTC along the Ciríaco, Branco and Décio pilot mines, at similar depth. Note the higher intensity of the gibbsite peak in the Ciríaco mine.

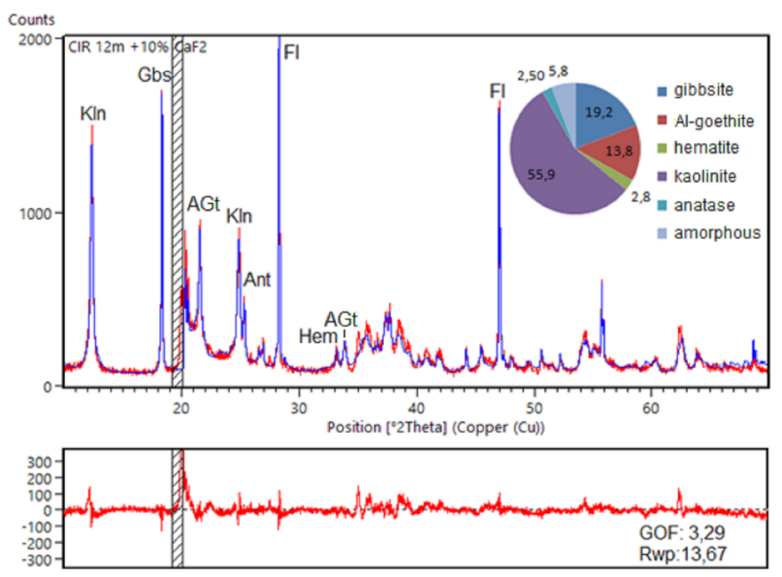

Kln: kaolinite, Gbs: gibbsite, AGt: Al-goethite, Qtz: quartz, Ant: anatase, Fl: fluorite (intern standard), GOF: good of fitness, Rwp: R weighted profile. Hachured: excluded of the refinement.

Figure 4. Rietveld refined diffractogram of the BTC $(12 \mathrm{~m})$ in the Ciríaco pilot mine. there is not any significant variation along the sequence, but higher concentrations than in the Círiaco are present.

Goethite is the second most abundant mineral in the BTC. It shows a relatively regular distribution (13.8 to $17 \%$ ) in the three pilot mines. Again, only the Ciríaco mine shows an increasing content from the bottom to the top. The Fe-Al substitution in the investigated goethite was calculated using the cell parameters obtained in the Rietveld refinement, after Schulze's (1984) method. This mineral has high $\mathrm{Al}$ contents (from 31.5 to $33.6 \mathrm{~mol} \%$ of $\mathrm{Al}$, Tab. 3) in the studied samples, representing the maximum possible substitution in synthetized goethites by Fitzpatrick \& Schwertman (1982), but is common in Al-rich rocks in the Amazon region (Negrão et al. 2017).

Gibbsite is the third most abundant phase in BTC (1.3 to $20.7 \%$ ), however it is much more concentrated in the Ciríaco mine $(20.7 \%$ at the bottom to $13.4 \%$ at the top). Gibbsite constitutes the main phase of the bauxitic nodules, which are abundant in the BTC of the Ciríaco mine. Despite that, it does not form a distinct horizon there as seen in the other pilot mines.

Hematite, anatase and quartz are less abundant. Hematite amounts up to a maximum $3.7 \%$ in the basis of the BTC, although it is absent or rare in the first meter at the top. Anatase shows similar distribution in the three pilot mines, ranging in contents from 2.4 to $2.9 \%$. Quartz occurs occasionally, normally reaching up to $1 \%$.

\section{Amorphous quantification}

Only amorphous silica and Fe oxyhydroxides have been investigated. Amorphous silica ranges from 0.39 to $0.83 \%$, whereas the amorphous $\mathrm{Fe}_{2} \mathrm{O}_{3}$ reaches up to $1.57 \%$ (Tab. 4). The data does not show any specific behavior among the three investigated pilot mines. The calculated $X$-ray amorphous (Feret 2013), on the other hand, shows much higher contents, varying broadly from 0.8 (Décio $10 \mathrm{~m}$ ) to $5.9 \%$ (Ciríaco $5 \mathrm{~m}$ ) and no relationship has been observed between depth or pilot mines.

The chemistry characterized Fe amorphous contents represents, excluding amorphous iron, some poor crystalline goethite and/or hematite, whereas part of the amorphous silica can be derived from the dissolution of poorly crystalline clay minerals (Saccone et al. 2007). Consequently, the much higher calculated $X$-ray amorphous (Feret 2013) contents cannot be directly compared to the $\mathrm{Si}$ and Fe amorphous, as it might be influenced by underestimations of not well-fitted minerals peaks during the Rietveld refinement.

\section{Micromorphology}

The mineral phases of the BTC in the three pilot mines occur as aggregates of nanometric crystals of kaolinite, 
The Belterra Clay on the bauxites of Rondon do Pará in Amazon

Table 2. Mineral composition of the BTC after Rietveld and stoichiometric quantification for comparison and evaluation.

\begin{tabular}{|c|c|c|c|c|c|c|c|c|c|c|c|c|c|}
\hline \multirow{2}{*}{$\begin{array}{l}\text { Pilot } \\
\text { mine }\end{array}$} & \multirow{2}{*}{$\begin{array}{c}\text { Depth } \\
\text { (m) }\end{array}$} & \multicolumn{2}{|c|}{ Kaolinite } & \multicolumn{2}{|c|}{ Al-Goethite } & \multicolumn{2}{|c|}{ Gibbsite } & \multicolumn{2}{|c|}{ Hematite } & \multicolumn{2}{|c|}{ Anatase } & \multicolumn{2}{|c|}{ Quartz } \\
\hline & & $\mathbf{R}$ & S & $\mathbf{R}$ & $\mathbf{S}$ & $\mathbf{R}$ & $\mathbf{S}$ & $\mathbf{R}$ & $\mathbf{S}$ & $\mathbf{R}$ & $\mathrm{S}$ & $\mathbf{R}$ & $\mathbf{S}$ \\
\hline \multirow{3}{*}{ Branco } & 0.8 & 70.2 & 72.3 & 17.5 & 17.5 & 4.2 & 2.2 & 0.5 & 0.5 & 2.4 & 2.4 & 1.5 & 1.5 \\
\hline & 5.5 & 72.8 & 75.1 & 16.1 & 15.8 & 3.1 & 1.7 & 1.6 & 1.6 & 2.7 & 2.5 & - & - \\
\hline & 10.5 & 73.0 & 73.6 & 15.0 & 15.9 & 4.6 & 1.8 & 2.1 & 2.1 & 2.4 & 2.6 & 0.3 & 0.3 \\
\hline \multirow{6}{*}{ Ciríaco } & 1.0 & 60.6 & 61.4 & 14.9 & 16.6 & 13.4 & 13.5 & - & - & 2.9 & 2.6 & 2.5 & 2.5 \\
\hline & 2.5 & 61.9 & 64.0 & 14.9 & 14.8 & 14.1 & 13.2 & 1.1 & 1.1 & 3.0 & 2.7 & 0.7 & 0.7 \\
\hline & 5.0 & 61.1 & 62.9 & 13.9 & 15.5 & 14.4 & 13.9 & 1.4 & 1.4 & 2.9 & 2.7 & 0.5 & 0.5 \\
\hline & 7.5 & 64.6 & 62.5 & 14.8 & 15.8 & 15.2 & 15.1 & 1.3 & 1.3 & 2.7 & 2.7 & - & - \\
\hline & 10 & 58.2 & 58.9 & 13.6 & 14.5 & 20.7 & 18.4 & 2.0 & 2.0 & 2.3 & 2.8 & 0.5 & 0.5 \\
\hline & 12 & 55.9 & 58.6 & 13.8 & 13.5 & 19.2 & 19.4 & 2.8 & 2.8 & 2.5 & 2.7 & - & - \\
\hline \multirow{4}{*}{ Décio } & 0.8 & 75.3 & 70.1 & 15.7 & 16.2 & 2.3 & 3.8 & - & - & 2.9 & 2.5 & 1.6 & 1.6 \\
\hline & 4.5 & 72.2 & 72.8 & 13.4 & 13.4 & 4.4 & 4.3 & 2.2 & 2.2 & 2.4 & 2.5 & 0.6 & 0.6 \\
\hline & 7.2 & 75.3 & 72.9 & 14.5 & 13 & 1.3 & 4.9 & 2.6 & 2.6 & 2.6 & 2.5 & - & - \\
\hline & 10 & 74.7 & 72.2 & 15.1 & 11.4 & 2.4 & 5.3 & 3.7 & 3.7 & 2.4 & 2.6 & - & - \\
\hline
\end{tabular}

R: Rietveld quantification, S: stoichiometric quantification after XRF chemical analyses, - : not identified.

Table 3. Al concentrations (mole \%) in goethites, calculated according to Schulze (1984).

\begin{tabular}{l|c|c|c}
\hline $\begin{array}{l}\text { Pilot } \\
\text { mine }\end{array}$ & $\begin{array}{c}\text { Depth } \\
(\mathbf{m})\end{array}$ & $\begin{array}{c}\text { c Al-goethite } \\
\text { cell parameter }\end{array}$ & $\begin{array}{c}\text { Al } \\
\text { (mole\%) }\end{array}$ \\
\hline \multirow{4}{*}{ Branco } & 0.5 & 2.966213 & 33.3 \\
\cline { 2 - 4 } & 5.5 & 2.967304 & 32.7 \\
\cline { 2 - 4 } & 10 & 2.964874 & 34.1 \\
\hline \multirow{5}{*}{ Ciríaco } & 1 & 2.969160 & 31.6 \\
\cline { 2 - 4 } & 2.5 & 2.969180 & 31.6 \\
\cline { 2 - 4 } & 5.0 & 2.968970 & 31.7 \\
\cline { 2 - 4 } & 7.5 & 2.968692 & 31.9 \\
\cline { 2 - 4 } & 10 & 2.967798 & 32.4 \\
\hline \multirow{5}{*}{ Décio } & 12 & 2.968117 & 32.2 \\
\hline & 0.8 & 2.970317 & 31.0 \\
\cline { 2 - 4 } & 4.5 & 2.967872 & 32.4 \\
\hline & 7.2 & 2.968450 & 32.0 \\
\cline { 2 - 4 } & 10 & 2.968293 & 32.1 \\
\hline
\end{tabular}

goethite and anatase, and microcrystalline gibbsite (Fig. 5). The size of their nanocrystalline minerals vary from 150 to $700 \mathrm{~nm}$, with lamellar pseudo-hexagonal morphology and well-defined edges in the larger crystals. Gibbsite generally forms the largest crystals, being micrometers in size (up to $10 \mu \mathrm{m}$ large), in veins and pockets inside of fragments of nodular bauxite (Fig. 5).

\section{Chemical composition}

The chemical composition of the BTC and its profile distribution along the pilot mines show (Fig. 6) the domain of $\mathrm{SiO}_{2}, \mathrm{Al}_{2} \mathrm{O}_{3}, \mathrm{Fe}_{2} \mathrm{O}_{3}$ and $\mathrm{TiO}_{2}$, which were expected after mineralogical composition. Together with the loss on ignition (LOI), they contribute to more than $99.6 \%$ of the bulk composition. The contents of each chemical component vary after each pilot mine and with the depth of the packet.

Results show that there is no contrast between the BTC from the Décio and Branco pilot mines after $\mathrm{SiO}_{2}, \mathrm{Al}_{2} \mathrm{O}_{3}$ and $\mathrm{TiO}_{2}$. On the other side, Branco comes out through with higher $\mathrm{Fe}_{2} \mathrm{O}_{3}$ contents. Chemically Ciríaco can be distinguished from both Branco and Decio, with the exception of $\mathrm{Fe}_{2} \mathrm{O}_{3}$.

The $\mathrm{SiO}_{2}$ contents increase from bottom to top, being much higher $(27.7 \%)$ at Décio and Branco. This reflects the slight increase of kaolinite contents along the packet, which is clear only for the Ciríaco mine. Kaolinite is the main $\mathrm{SiO}_{2}$ carrier in the BTC, since the amounts of quartz rarely exceed $1 \%$.

The $\mathrm{Al}_{2} \mathrm{O}_{3}$ distribution is inverse to that of $\mathrm{SiO}_{2}$, decreasing from bottom to top along the three pilot mines, showing higher concentrations at Ciríaco. This behavior displays the concentration of gibbsite in the lower part of the packets. Besides kaolinite and gibbsite, the Al-rich goethite also contributes to the high $\mathrm{Al}$ contents. 
Table 4. Weight contents of $\mathrm{SiO}_{2}$ and $\mathrm{Fe}_{2} \mathrm{O}_{3}$ amorphous in the BTC of the Branco (BRC), Círiaco (CIR) and Décio (DEC) pilot mines, and of X-ray amorphous quantified with internal standard fluorite after XRD Rietveld method.

\begin{tabular}{l|c|c|c|c|c}
\hline Pilot mine & Depth & amorphous $\mathrm{SiO}_{2}$ & amorphous $\mathrm{Fe}_{2} \mathbf{O}_{3}$ & $\mathbf{S i O}_{2}+\mathrm{Fe}_{2} \mathbf{O}_{3}$ (amorphous) & X-ray amorphous (Rietveld) \\
\hline \multirow{4}{*}{ Branco } & 0.8 & 0.75 & 0.71 & 1.46 & 3.7 \\
\cline { 2 - 6 } & 5.5 & 0.83 & 0.40 & 1.23 & 3.8 \\
\cline { 2 - 6 } & 10.5 & 0.62 & 0.26 & 0.88 & 2.6 \\
\hline \multirow{5}{*}{ Ciríaco } & 1.0 & 0.53 & 0.86 & 1.39 & 5.7 \\
\cline { 2 - 6 } & 2.5 & 0.43 & 0.60 & 1.03 & 4.9 \\
\cline { 2 - 6 } & 5.0 & 0.43 & 0.49 & 0.91 & 5.9 \\
\cline { 2 - 6 } & 7.5 & 0.51 & 0.43 & 0.94 & 1.2 \\
\cline { 2 - 6 } & 10 & 0.39 & 0.74 & 1.13 & 2.8 \\
\cline { 2 - 6 } & 12 & 0.43 & 0.89 & 1.31 & 3.8 \\
\hline \multirow{5}{*}{ Décio } & 0.8 & 0.82 & 0.71 & 1.53 & 4.8 \\
\cline { 2 - 6 } & 4.5 & 0.73 & 0.83 & 1.56 & 3.8 \\
\hline
\end{tabular}
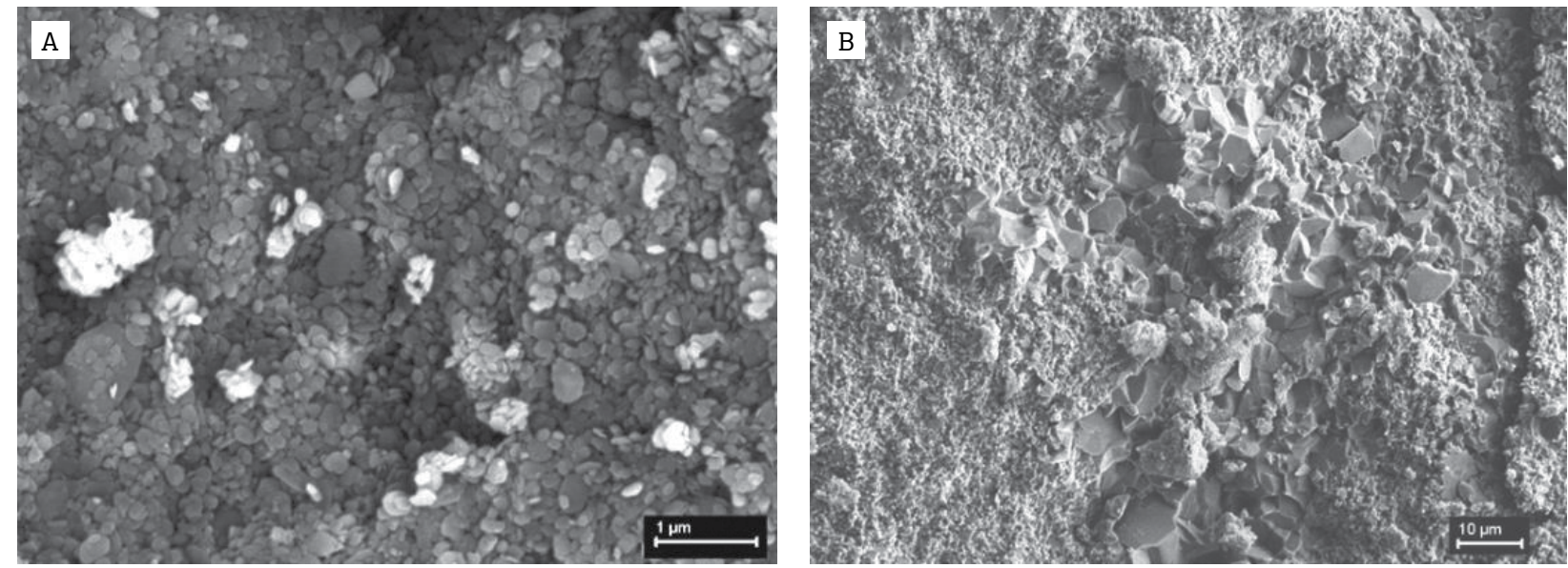

Figure 5. SEM image of the BTC in (A) Décio pilot mine at $4.5 \mathrm{~m}$, showing indistinguishable nanometric size crystals, where the lighter crystals represent iron oxi-hydroxide minerals; in (B) Branco pilot mine at $10 \mathrm{~m}$, showing the interior of a bauxitic nodules with pocket of micrometric well shaped gibbsite crystals within the very fine matrix made of nanometer large gibbsite-kaolinite mass.

Similarly, to $\mathrm{Al}_{2} \mathrm{O}_{3}$, the $\mathrm{Fe}_{2} \mathrm{O}_{3}$ concentrations generally decrease from bottom to the top of the BTC packets, being much more concentrated at the Branco mine. These contents are ruled by the presence of $\mathrm{Al}$-goethite and hematite, being this last absent at the top of the BTC. The $\mathrm{TiO}_{2}$ concentrations do not show any clear relationship to depth, as it is significantly higher at Ciríaco mine (from 2.59 to $2.79 \%$ ). Anatase is the main $\mathrm{TiO}_{2}$ phase identified.

\section{Thermal behavior}

The BTC in Rondon do Pará displays four typical mass losses (Fig. 7). A first derivate of the thermogravimetric curve (DTG) and the DTA clearly shows the peaks of each mass loss.

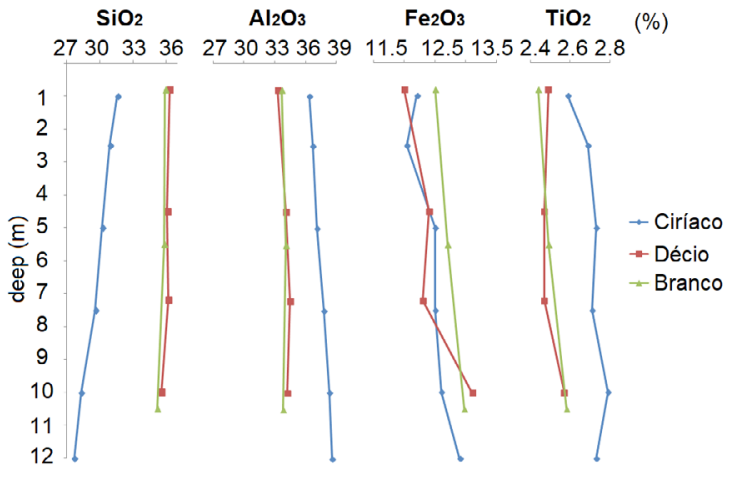

Figure 6. Distribution of the concentrations of the main chemical components, with the depth, of the three pilot mines 
The first mass loss (between 25 and $110^{\circ} \mathrm{C}$ ) represents the adsorbed water within the material particles (Földvári 2011). The second loss (between 210 and $270^{\circ} \mathrm{C}$ ) is attributed to the decomposition of gibbsite to form $\rho$-alumina, amorphous to XRD (Ingram-Jones et al. 1996). According to Colombo \& Violante (1996), differential thermal analyses of gibbsite commonly shows an endotherm peak close to $230^{\circ} \mathrm{C}$, followed by another at $280^{\circ} \mathrm{C}$. The latter is observed when gibbsite is transformed into bohemite, due to a hydrothermal reaction provided by the water adhered on the particles of this mineral. However, even in richer gibbsite samples from the Ciríaco pilot mine, this latter peak was not noticed, suggesting that gibbsite was directly transformed into $\rho$-alumina.

The dehydroxylation of $\mathrm{Al}$-goethite occurs at temperatures close to $300^{\circ} \mathrm{C}$, forming hematite (Schulze \& Schwertmann 1984). Gualtieri \& Venturelli (1999) reported the presence of two endothermic peaks in the DTA curve of synthesized goethites. Gialanella et al. (2010), however, observed that natural goethites exhibit a single endothermic peak, which may be common in nanometric goethites, expected to have higher specific surface area (Walter et al. 2001). In the observed samples, the decomposition of this mineral occurs in temperatures between $276^{\circ}$ and $370^{\circ} \mathrm{C}$, represented by only one endothermic peak with a maximum loss around $360^{\circ} \mathrm{C}$ in the DTG curve, which confirms its nanometric crystal sizes.

At temperatures close to $500^{\circ} \mathrm{C}$, kaolinite dehydroxylates to form metakaolinite $\left[\left(\mathrm{Al}_{2} \mathrm{O}_{3} \cdot 2 \mathrm{SiO}_{2}\right)\right]$ (Yeskis et al., 1985). In the investigated samples this process corresponds to the fourth loss mass, starting from $390^{\circ}$ until approximately $590^{\circ} \mathrm{C}$, being represented by an endotherm with a maximum peak around $500^{\circ} \mathrm{C}$. At temperatures close to $980^{\circ} \mathrm{C}$, metakaolinite transforms into mullite $\left(\mathrm{Al}_{6} \mathrm{Si}_{2} \mathrm{O}_{13}\right)$ (Chakraborty \& Ghosh 1978, Chen et al. 2004), as observed at the exothermic peak in the DTA curves.

The well individualized mass losses observed in the thermogravimetric analyses indicates the predominance of kaolinite, after goethite and gibbsite, being this last mineral clearly more abundant in the Ciríaco mine. The thermal behavior of the analyzed materials is also in accordance with the content of the individual minerals present in the samples after XRD Rietveld and stoichiometric quantifications.
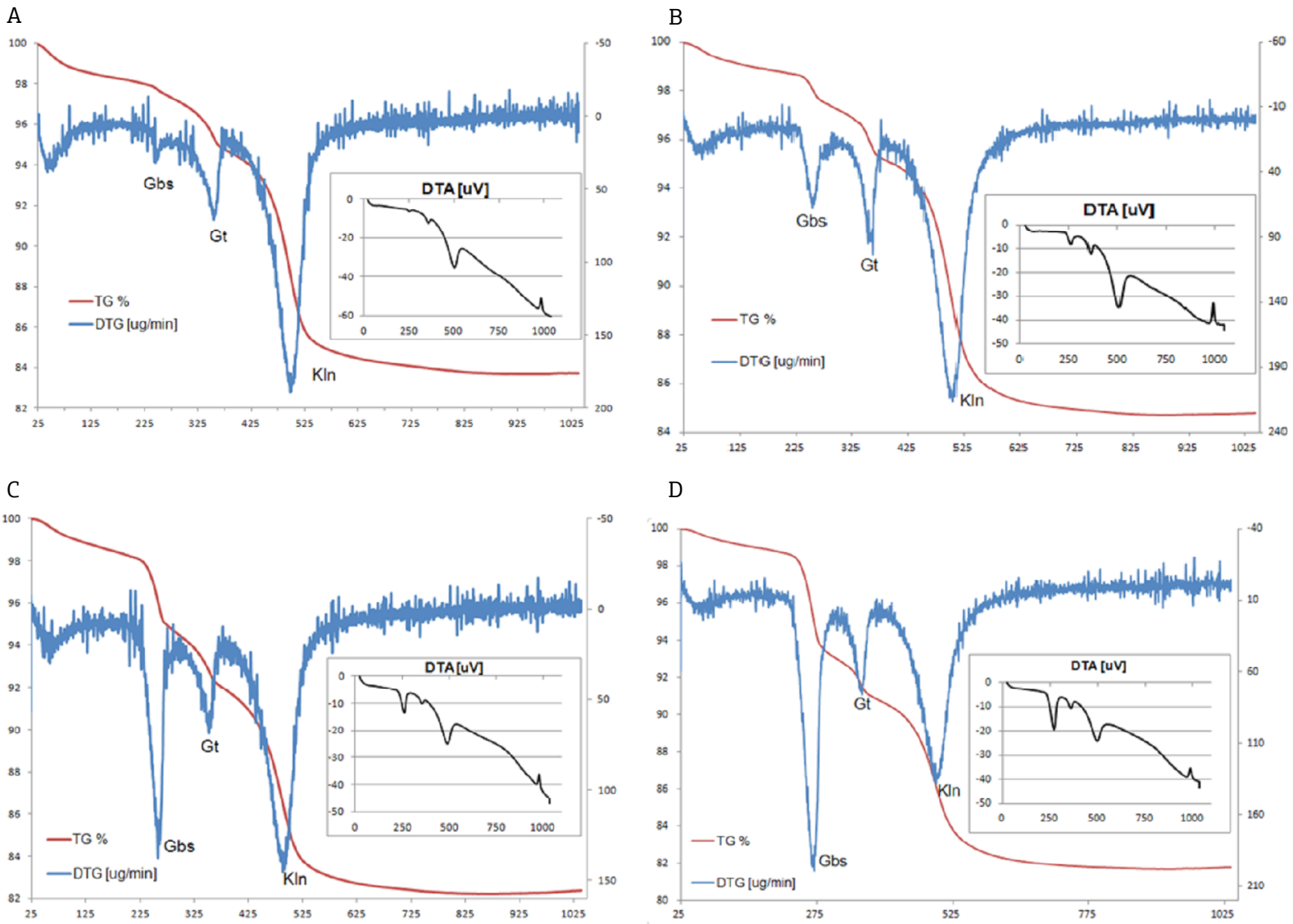

Gbs: gibbsite, Gt: goethite, Kln: kaolinite. Heating rate: $10^{\circ} \mathrm{C} / \mathrm{min}$.

Figure 7. Thermogravimetric analysis (TGA), its derivate (DTG) and differential thermal analysis (DTA) of BTC: (A) Branco at $0.5 \mathrm{~m}$; (B) Branco $10.5 \mathrm{~m}$; (C) Ciríaco at $1.0 \mathrm{~m}$; (D) Ciríaco $12 \mathrm{~m}$. 
The particularly high $\mathrm{Al}$ contents in the structure of the goethites of up to $33 \mathrm{~mol} \%$ influenced the incorporation of nonstoichiometric hydroxyl units in the goethite structure (Laskou et al. 2006). The Al-goethite is thermally more stable and dehydroxylates at higher temperatures (Ruan et al. 2002) with the maximum loss around $360^{\circ} \mathrm{C}$ in the studied BTC samples, whereas the dehydroxylation of $\mathrm{Al}$-free goethites occurs near to $300^{\circ} \mathrm{C}$ (Schulze \& Schwertmann 1984).

\section{DISCUSSION}

The geological characteristics of the BTC in Rondon do Pará can be well correlated to BTC from other bauxite deposits of Paragominas, Juruti, Oriximiná and surround BTC near Manaus, presenting the same mineralogical constitution (Truckenbrodt et al. 1991, Horbe \& Costa 1999, Horbe \& Costa 2005, Kotschoubey et al. 2005, Balan et al. 2005, Costa et al. 2014, Negrão et al. 2018). The color of BTC from reddish yellow to ochreous at the top of the lateritic profile also shows its affinity to the lateritic profile. Main chemical (Fig. 8) differences are restricted to $\mathrm{Fe}_{2} \mathrm{O}_{3}$ concentrations, higher in all pilot mines at Rondon do Pará and Manaus, reflecting the source rock composition or even iron remobilization. The $\mathrm{Al}_{2} \mathrm{O}_{3}$ concentrations in Oriximiná are also much higher, attesting a more gibbsitic BTC there. The general pattern of higher $\mathrm{Al}_{2} \mathrm{O}_{3}$ and $\mathrm{TiO}_{2}$ contents in the bottom of the packets, decreasing to the top is common in all BTC's, further attesting their high similarity.

The mineralogy of the BTC involves the same mineral species of the laterite-bauxite profile (Oliveira et al. 2016), differing only in their respective proportions. This composition is fast homogeneous in every BTC package, but varies close to the contact with the underlying lateritic profile, reinforcing the affinity between them, having the laterite-bauxite profile certainly as source material. While gibbsite is the main mineral at the top of the lateritic profile together with hematite and goethite, it is found restricted to the base of the $\mathrm{BTC}$, reinforcing that it is the main source of its constituents. Resilication was probably the main process transforming gibbsite into kaolinite, as suggested by Dangić (1985), Lucas et al. (1993), Liu et al. (2010) and Mateus et al. (2017), while the source of silica was from the rather unknown massive ancient forest (Lucas et al. 1993).

The kaolinite is the main mineral of the BTC, which is also frequent in the lateritic profile, especially when it is heavily weathered. This mineral presents a very distinct diffraction

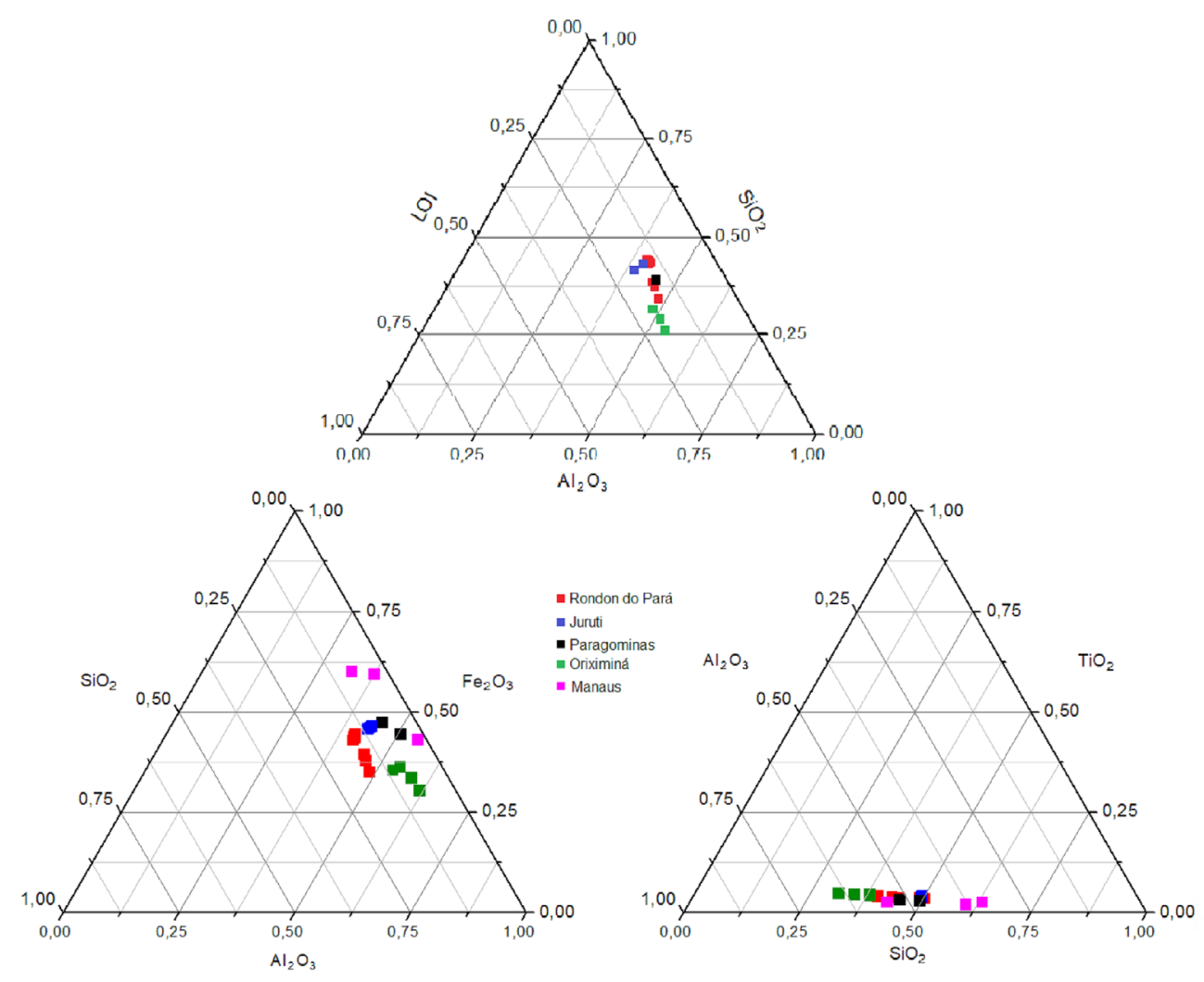

Figure 8. Ternary diagram showing the similar but distinct chemistry of the Belterra Clay in Rondon do Pará, over the bauxite deposits of Juruti, Paragominas, Oriximiná, and location near to Manaus. 
pattern when compared to the kaolinites described in the Inorganic Crystal Structures Database (ICSD, Karlsruhe) files. The BTC kaolinite in Rondon do Pará is poorly ordered with typical stacking faults affecting mainly the $34^{\circ}-40^{\circ} 2 \Theta(\mathrm{Cu})$ region, where its anomalous diffraction pattern resulted in not well-fitted diffraction peaks of this phase (Fig. 4), partially prejudicing the Rietveld refinement in these regions. Not by chance, the most discrepant contents when comparing Rietveld and stoichiometric results (Tab. 2) are addressed to kaolinite.

Poor ordered-like kaolinites were also investigated by Giral-Kacmarcik et al. (1998) in latosols compared to BTC near Manaus, Amazonia. These kaolinites are not inherited from underlying sedimentary rocks, and the increasing disorder of this mineral might be a result of parent rock minerals transformation through dissolution-recrystallization processes in rain forests, as stated by Lucas et al. (1993). Balan et al. (2005) used paramagnetic radiation-induced defects of kaolinites from latosols (up to $16 \mathrm{~m} \mathrm{depth}$ ) localities near the city of Manaus, related to BTC, to estimate the age of formation of these materials. The authors obtained Miocene-Pliocene ages for the nodular horizons within the latosols, whereas the upper part of these latosols displays evidences of more recent (from 5.7 to $9.7 \mathrm{Ma}$ ) formation of kaolinite and physical reworking of the soil by biologic activity.

$\mathrm{Al}$-goethite is more frequent in BTC than in the underlying lateritic profile. $\mathrm{Al}$-goethite is a typical mineral of tropical soils, mainly derived from iron rich aluminous rocks, such as lateritic bauxite crusts. The near absence of quartz at the top of the lateritic profile and in the BTC also goes to find this genetic inheritance.

The BTC cover in Rondon do Pará consists altered lateritic profiles, especially in its upper part, which can be well related to a typical alteration of paleotropical weathering indicated by the domain of kaolinite, goethite and anatase (Fig. 9). The accumulation of iron spherulites and bauxitic nodules at the contact with the lateritic profile, suggests proximal erosion and rapid sedimentation by debris flow in semiarid conditions. The paleochannel cutting the top of the lateritic profile (Fig. 2B) reinforces erosion processes, which is also displayed by the geological contact with the underlying lateritic profile, generally abrupt, undulated and with occurrence of nodular bauxite zone and/or iron spherulites.

The following accumulation of kaolinite, goethite and anatase shows that paleotropical weathering and erosion took place contemporaneously for a long time in order to form the thick clay packet, probably during the late Miocene/ Pliocene according to similar BTC expositions (Balan et al. 2005, Costa et al. 2014).

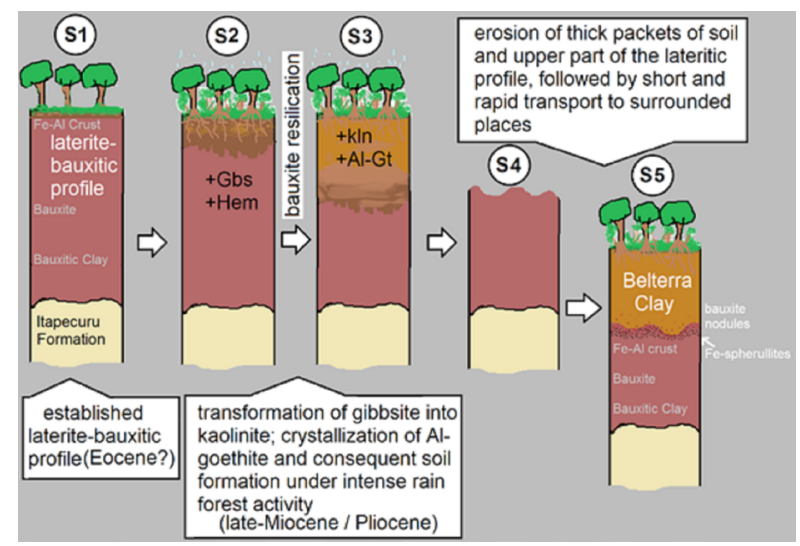

Figure 9. Simplified model (not in scale) of the Belterra Clay formation and establishment in Rondon do Pará in stages (S). (S1) fresh established lateritic profile during Eocene; (S2) soil formation from the lateritic profile under intense rain tropical forest, note the root activity during the bauxite resilication to transform gibbsite (Gbs) into kaolinite (Kln) by silica input and crystallization of Al-goethite (Al-Gt), whereas hematite (hem) and gibbsite are enriched in the bauxite profile; (S3) thick soil of Belterra Clay formed on the lateritebauxite profile and enriched in kaolinite and Algoethite; (S4) erosion of Belterra Clay and upper part of the lateritic profile under arid conditions during Pliocene; (S5) short and rapid transport to surround eroded lateritic profiles with irregular surface, establishing the actual configuration of BTC in Rondon do Pará. Ages are estimated after Costa et al. (2014) to similar BTC occurence.

\section{CONCLUSIONS}

The kaolinite of the BTC has a high structural disorder, or it may be a variation of kaolinite structure not yet described in published crystallographic models. The goethite is in fact aluminous, with up to $33 \%$ (mol) of $\mathrm{Al}$ in its structure. These two minerals, along with gibbsite, are responsible for up to $38.6 \%$ of $\mathrm{Al}_{2} \mathrm{O}_{3}$ in the $\mathrm{BTC}$, characterizing it as high alumina clay.

In general terms, the minerals of the BTC are the same of the underneath laterite-bauxite profile. Its flat geometry, chemistry and mineralogy can be correlated to the BTC covering other bauxite deposits in the Amazon region, especially those of Paragominas, Juruti and Oriximiná regions.

The similarity among the BTC in Rondon do Pará and other occurrences along the Amazon region suggests these materials likely experienced genesis and evolution from the underlying laterite-bauxitic profiles. The sharp contacts of BTC over the upper horizons of the laterite-bauxitic profiles (mainly bauxites) evidence its short transport and local deposition in Rondon do Pará. 


\section{ACKNOWLEDGEMENTS}

The authors thank Votorantim Metais for the access to its Rondon do Pará research areas, for the support and for allowing the collection of samples along the pilot mines. Financial support of the Brazilian National Research Council (CNPq) through research grants (Nr. 304.519/2009-0; 477411/2012-6) and the INCT - GEOCIAM/CNPq (Project Nr. 573733/2008-2) are gratefully acknowledged.

\section{REFERENCES}

Abouchami W., Näthe K., Kumar A., Galer S.J.G., Jochum P.K., Williams E., Horbe A.M.C., Rosa J.W.C., Balsam W., Adams D., Mezger K., Andreae M.O. 2013. Geochemical and isotopic characterization of the Bodélé Depression dust source and implications for transatlantic dust transport to the Amazon Basin. Earth and Planetary Science Letters, 380:112-123. http://doi.org/10.1016/j.epsl.2013.08.028

Balan E., Allard T., Fritsch E., Sélo M., Falgueres C., Chabaux F., Pierret M.C., Calas G. 2005. Formation and evolution of lateritic profiles in the middle Amazon bassin Insights from radiation-induced defects in kaolinite. Geochimica et Cosmochimica Acta. 69:2193-2204. http://doi.org/10.1016/j.gca.2004.10.028

Bardossy G., Aleva G.J.J. 1989. The Amazon Basin. A discussion review. Travaux ICSOBA, 19: 445-458.

Barreto I.A.R., Costa M.L. 2018. Sintering of red ceramics from yellow Amazonian latosols incorporated with illitic and gibbsitic clay. Applied Clay Science, 152:124-130. https://doi.org/10.1016/j.clay.2017.11.003

Bish D.L., Von Dreele R.B. 1989. Rietveld refinement of non-hydrogen atomic positions in kaolinite. Clays and Clay Minerals, 37(4):289-296.

Bizzi L.A., Schobbenhaus C., Vidotti R.M., Gonçalves J.H (Eds.). 2003. Geologia, tectônica e recursos minerais do Brasil: Texto, mapas and SIG: Brasília, Serviço Geológico do Brasil. Brasília, Companhia de Pesquisa de Recursos Minerais, $692 \mathrm{p}$.

Chakraborty A.K.. Ghosh D.K. 1978. Reexamination of the kaoliniteto-mullite reaction series. Journal of America Ceramic Society, 61:170-173. https:/doi.org/10.1111/j.1151-2916.1978.tb09264.x

Chen Y.F., Moo-Chin W., Hon M.H. 2004. Phase Transformation and Growth of Mullite in Kaolin Ceramics. Journal of the European Ceramic Society, 24(8):2389-2397. https://doi.org/10.1016. S0955-2219(03)00631-9

Colombo C., Violante A. 1996. Effect of time and temperature on the chemical composition and crystallization of mixed iron aluminum species. Clays and Clay Minerals, 44:113-120. http://doi.org/10.1346/ CCMN.1996.0440110

Costa M.L., Silva Cruz G., Faria de Almeida H.D., Pöllmann H. 2014 On the geology, mineralogy and geochemistry of the bauxite-bearing regolith in the lower Amazon basin: Evidence of genetic relationships. Journal of Geochemical Exploration, 146:58-74. https://doi.org/10.1016/j.gexplo.2014.07.021

D’Amour H., Denner W., Schulz H. 1979. Structure determination of alpha-quartz up to $68 * 108$ Pa. Acta Crystallographica B, B35:550-555. https://doi.org/10.1107/S056774087900412X

Dangić A. 1985. Kaolinization of bauxite: a study in the Vlasenica Bauxite area, Yugoslavia. I. Alteration of matrix. Clays Clay Minerals, 33(6):517-524. https://doi.org/10.1346/CCMN.1985.0330606

DeMaster D.J. 1981. The supply and accumulation of silica in the marine environment. Geochimica et Cosmochimica Acta, 45:1715-1732. https://doi.org/10.1016/0016-7037(81)90006-5

Dennen W.D. \& Norton H.A. 1977. Geology and geochemistry of bauxite deposits in the lower Amazon basin. Economic Geology, 72:82-89. https://doi.org/10.2113/gsecongeo.72.1.82
Feret F.R. 2013. Selected Applications of Rietveld-XRD Analysis for Raw Materials of the Aluminum Industry. Powder Diffraction 28(2):112-123. https://doi.org/10.1017/S088571561300016X

Fitzpatrick R.W., Schwertmann O. 1982. Al-substitued goethite, an indicator of pedogenic and other weathering environments in South Africa. Geoderma, 27(4):335-347. https://doi. org/10.1016/0016-7061(82)9022-2

Földvári M. 2011. Handbook of thermogravimetric system of minerals and its use in geological practice. Budapest, Geological Institute of Hungary, $40 \mathrm{p}$.

Gialanella S., Girardi F., Ischia G., Lonardelli I., Mattarelli M., Montagna M. 2010. On the goethite to hematite phase transformation. Journal of Thermas Analysis and Calorimetry, 102(3):867-873.

Giral-Kacmarcik S., Savin S.M., Nahon D.B., Girard J.-P., Lucas Y., Abel L. 1998. Oxygen isotope geochemistry of kaolinite in laterite-forming processes, Manaus, Amazonas, Brazil. Geochimica et Cosmochimica Acta, 62:1865-1879. https://doi.org/10.1016/ S0016-7037(98)00103-3

Gualtieri A., Venturelli P. 1999. In situ study of the goethite-hematite phase transformation by real time synchrotron powder diffraction. American Mineralogist, 84:895-904. https://doi.org/10.2138/ am-1999-5-624

Horbe A.M.C., Costa M.L. 1997. Solos gerados a partir do intemperismo de crostas lateríticas sílico-ferruginosas. Acta Amazônica 27:241-256. https://dx.doi.org/10.1590/1809-43921997274256

Horbe A.M.C., Costa M.L 1999. Genetic relationship between lateritic duricrusts and soils in the Amazonian region - Brazil. In: McClenaghan M.B (Ed.). International Geochemical Exploration Symposium. Abstracts Volume... Vancouver, p. 123-124.

Horbe A.M.C., Costa M.L. 2005. Lateritic crust and related soils in eastern Brazilian Amazonia. Geoderma, 126:225-239. https://dx.doi. org/10.1016/j.geoderma.2004.09.011

Ingram-Jones V.J., Slade R.C.T., Davies T.W, Southern J.C., Salvador S. 1996. Dehydroxylation sequences of gibbsite and boehmite: study of differences between soak and flash calcination and of particle-size effects Journal of Materials Chemistry, 6: 73-79. https://dx.doi. org/10.1039/JM9960600073

Kotschoubey B., Calaf J.M.C., Lobato A.C.C., Leite A.S., Azevedo C.H.D. 2005. Caracterização e Gênese dos Depósitos de Bauxita da Província Bauxitífera de Paragominas, Noroeste da bacia do Grajaú, Nordeste do Pará/Oeste do Maranhão. In: Jost H., Queiroz E.T. (Eds.). Caracterização de Depósitos Minerais em Distritos Mineiros da Amazônia. Brasília, ADIMB/DNPM, p. 691-782.

Kronberg B.I., Fyfe W.S., McKinnon B.J., Couston J.F., Stilianid F.B., Nash R.A. 1982. Model for bauxite formation: Paragominas (Brazil). Chemical Geololy, 35(3-4):311-320. https://doi. org/10.1016/0009-2541(82)90008-0

Laskou M., Margomenou-Leonidopoulou G., Balek V. 2006. Thermal characterization of bauxite samples. Journal of Thermal Analysis and Calorimetry, 84:141-146. https://doi.org/10.1007/ s10973-005-7126-5 
Li D., O' Connor B.H., Low I.M., van Riessen A., Toby B.H. 2006. Mineralogy of Al-substituted goethites. Powder Diffraction, 21:289-299. https://dx.doi.org/10.1154/1.2358358

Liu X., Qingfei W., Deng J., Zhang Q., Sun S., Meng J. 2010. Mineralogical and geochemical investigations of the Dajia Salento-type bauxite deposits, western Guangxi, China. Journal of Geochemical Exploration, 105:137-152. https://dx.doi.org/10.1016/j.geoplo.2010.04.012

Lucas Y., Luizão F.J., Chauvel A., Rouiller J., Nahon D. 1993. The relation between biologic activity of the rain forest and mineral composition of soils. Science, 260:521-523. https:// doi.rog/10.1126/ Science.260.5107.521

Mateus A.C.C., Oliveira F.S., Varajão A.F.D.C., Soares C.C.V. 2017. Genesis of soils from bauxite in southeastern Brazil: resilication as a soil-forming process. Revista Brasileira de Ciência do Solo, 41:e0160507. http://dx.doi.org/10.1590/18069657rbcs20160507

McKeague J.A. \& Day J.H. 1966. Dithionite and oxalate extractable $\mathrm{Fe}$ and $\mathrm{Al}$ as aids in differentiating various classes of soils. Canadian Journal of Soil Science, 46:13-22. https://doi.org/10.4141/cjss66-003

Negrão L.B.A., Costa M.L., Poellmann H., Abreu D.S., Silva A.C.S, Santos P.H.C. 2017. Quantificação de Al em goethitas e hematitas de Salinópolis-PA e de perfis lateríticos de Carajás, Juruti e Rondon do Pará (Amazônia Oriental). In: Lima A.M.M., Gorayeb P.S.S. (Eds.). Contribuições à geologia da Amazônia. SBG, v. 10, 400 p.

Negrão L.B.A., Da Costa M.L., Pöllmann H., Horn A. 2018. An application of the Rietveld refinement method to the mineralogy of a bauxite bearing regolith in the Lower Amazon. Mineralogical Magazine, 1-18. https://doi.org/10.1180/minmag.2017.081.056

Oliveira S.B., Costa M.L., Prazeres Filho H.J. 2016. The lateritic bauxite deposit of Rondon do Pará: A new giant deposit in the Amazon Region, Northern Brazil. Economic Geology, 111(5):1277-1290. https://doi.org/10.2113/econgeo.111.5.1277

Pantoja H.M. 2015. Mineralogia, geoquímica e minerais pesados do peril laterito-bauxítico com cobertura e sua relação com o Grupo Itapecuru: Lavra piloto Círiaco (Rondon do Pará). MS Dissertation, Instituto de Geociências, Universidade Federal do Pará, Belém, 70 p.

Prazeres Filho H.J., Oliveira S.B., Molinari L., Belther J. 2015. The rediscovery of Rondon do Para, the last giant world-class bauxite deposit in an attractive geography. In: ICSOBA Proceedings, 33, Dubai, United Arab Emirates.

Rietveld H.M., 1969. A profile refinement method for nuclear and magnetic structures. Journal of Applied Crystallography, 2:65-71. https://doi.org/10.1107/S0021889869006558

Rossetti D.F. 2004. Paleosurfaces from northeastern Amazonia as a key for reconstructing paleolandscapes and understanding weathering products. Sedimentary Geology, 169:151-174.https://doi. org/10.1016/j.sedgeo.2004.05.003

Ruan H.D., Frost R.L., Kloprogge J.T., Duong L. 2002. Infrared spectroscopy of goethite dehydroxylation. II. Effect of aluminium substitution on the behaviour of hydroxyl units. Spectrochimica Acta, 58(3):479-491.
Saalfeld H., Wedde M. 1974. Refinement of the crystal structure of gibbsite, $\mathrm{Al}(\mathrm{OH}) 3$. Zeitschrift Fur Kristallographie, 139:129-135. http://dx.doi.org/10.1524/zkri.1974.139.1-2.129

Saccone L., Conley D.J., Koning E., Sauer D., Sommer M., Kaczorek D., Blecker S.W., Kelly E.F. 2007. Assessing the extraction and quantification of amorphous silica in soils of forest and grassland ecosystems, European Journal of Soil Science, 58:1446-1459. https:// doi.org/10.1111/j1365-2389.2007.00949.x

Sadykov V.A., Isupova L.A., Tsybulya S.V., Cherepanova S.V., Litvak G.S., Burgina E.B., Kustova G.N., Kolomiichuk V.N., Ivanov V.P., Paukshtis E.A., Golovin A.V., Avvakumov E.G. 1996. Effect of mechanical activation on the real structure and reactivity of iron (III) oxide with corundum-type structure, Journal of Solid State Chemistry, 123:191202. https://doi.org/10.1006/jssc.1996.0168

Schulze D.G. 1984. The influence of aluminum on iron oxides. VIII. Unit-cell dimensions of Al-substituted goethites and estimation of Al from them. Clays and Clay Minerals, 32:36-44. https://doi. org/10.1346/CCMN.1984.0320105

Schulze D.G. \& Schwertmann U. 1984. The influence of aluminium on iron oxides: X. Properties of A-substituted goethites. Clay Minerals, 19:521-539.

Sombroek W.G. 1966. Amazon soils. A reconnaissance of the soils of the Brazilian Amazon region. Wageningen, Wageningen University, 24, $292 \mathrm{p}$.

Sonnerveld E.J. \& Visser J.W. 1975. Automatic collection of powder data from protographs. Journal of Applied Crystallography, 8: 1-7. http://doi.org/10.1107/S0021889875009417

Tardy Y. 1993. Pétrologie des laterites et des sois tropicaux. Paris, Masson, $459 \mathrm{p}$

Truckenbrodt W., Kotschoubey B. 1981. Argila de Belterra Cobertura terciária das bauxitas amazônicas. Revista Brasileira de Geociências, 11(3):203-208

Truckenbrodt W., Kotschoubey B., Shellmann W. 1991. Composition and origin of the clay cover on north Brazilian laterites. Geoligische Rundschau, 80:591-610. https://doi.org/10.1007/BF01803688

Walter D., Buxbaum D., Laqua W. 2001. The mechanism of the thermal transformation from goethite to hematite. Journal of Thermal Analysis and Calorimetry, 63:733-748. https://doi. org/10.1023/A:1010187921227

Williams E., Eberl D., Rosa J.W., Adams D.K., Todd M., Bou Karam D., Huang S., Balsam W., Renno N.O. 2010. Belterra Clay in Brazil: Addressing the Africa dust hypothesis. In: Eos Trans. AGE 91 (26) Meet. Am. Suppl. Anais... Abstract A43A-07.

Weirich T.E., Winterer M., Seifried S., Hahn H., Fuess H. 2000. Rietveld analysis of electron powder diffraction data from nanocrystalline anatase, TiO2. Ultramicroscopy, 81:263-270

Yeskis D., Koster van Groos A.F., Guggenheim S. 1985. The dehydroxylation of kaolinite. American Mineralogist, 70:159-164.

This is an open access article distributed under the terms of the Creative Brasileira de Geologia 